\title{
Examining the Implementation of Community Policing Program in Maintaining Peace and Security in the Case of Maychew Town, Southern Tigray, Ethiopia
}

\author{
Alexander Haymanot Abrha \\ Lecturer, Department of Civic and Ethical Studies, College of Social Science and Humanity, Raya University, \\ P.O. Box 92, Maychew, Ethiopia.
}

\begin{abstract}
The overall objective of this study was to examine the Implementation of Community Policing Program in Maintaining Peace and Security in the Case of Maychew Town, Southern Tigray, Ethiopia. Despite the expected benefits of the strategy, the numbers of crimes committed were still increasing in the alarming situation in the Town. The strategy has to be researched and as per the researcher's observation, no research either pre or post implementation of community policing program was conducted in the study area. The study used qualitative research methodology and it was based on an explanatory research design. The target populations of this study were the community house-holds (family police) and the community policing officers who were working in the implementation of community policing program in the study area. The study sampled 24 respondents who were selected trough purposive sampling techniques from the police and the community. The researcher employed both primary and secondary sources and data was collected using semi-structured interview and FGD. The qualitative data was analyzed and interpreted through a combination of interpretivism and constructivism methods. All in all, the study concludes that the implementation of community policing program in maintaining peace and security was not effective in the study area. It is therefore, recommended that the police, the community, the government and any concerned body should work cooperatively and gives emphasis to the program in order to maintain peace and security in the study area.
\end{abstract}

Keywords: Examining, Implementation, Community Policing Program, Maychew, Ethiopia

DOI: $10.7176 / \mathrm{JCSD} / 49-01$

Publication date:June $30^{\text {th }} 2019$

\section{Introduction}

\subsection{Background of the study}

Crime causes social, economic, health and psychological effects on victims and the community as a whole. Crime directly reduces the quality of life of individuals and the communities. To respond to such problems, governments have launched the polity as an institution by which the police are recruited, trained and deployed (Block et al., 2011).

However, traditionally, maintaining peace and security of the community has been considered as the exclusive role of the police without the active involvement of the community. As a result, the police were not successful in preventing crime without the involvement of the community. It was in reaction to this gap that the concept of community policing was introduced (Palmiotto, 2000). Community policing is a collaborative work between the police and the community to maintain peace and security of the public (Mekuriaw and Mulugeta, 2017).

All over the world, there is a move away from traditional policing (top-down, passive and reactive in nature) to community policing. This is based on the key tenet of community policing that the police should not be separate from, but rather joined in partnership with the community (Ford and Morash, 2002). During the 1970s, some experimentation with community and neighborhood based policy projects had conducted across nations of the world. However, in the early 1980s, the outlines of a new direction for policing, known as community policing began to emerge and taken root in the US and many of its features were widely supported by the public and the media (Skolnick, 2003).

Community policing is also one of the new strategic approach that the Ethiopian government is introduced as a crime prevention strategy. The concept of community policing first introduced in Ethiopia in 1989 E.C. However, it couldn't put in action due to different reasons until 2002. Some of the reasons were lack of management and bad community perception about community policing, inadequate government budget to support its activities, and lack of skilled police force that specialized on community policing (Frehiwot, 2015).

According to Yeshiwas (2014), since 2002, Business Process Reengineering (BPR) as a reform process in the police organization has been undergoing in many police departments throughout Ethiopia aimed at institutional improvement and better service delivery. In light with the policy of decentralization in Ethiopia, in 2011 G.C, the Tigray Regional State Police Commission adopted a community policing program as a crime prevention strategy.

Since 2011 G.C, the community policing program has already been implemented in Maychew Town. Despite the introduction of community policing, diversified, complex and serious crimes in huge numbers are still 
committed in the Town. In Maychew Town, on average, the total crimes committed in the years 2008, 2009 and 2010 were 34, 41, and 58 respectively (Community Policing Officer, Personal Communication, October 14, 2018).

\subsection{Statement of the Problem}

The Ethiopian Government initiated community policing program in order to improve the poor police-community relationship thereby addressing the security challenge. In 2003 E.C, members of the Ethiopian Federal Police took community policing training provided by British trainers in Addis Ababa. Moreover, some senior officers travelled to Europe to undertake further training and then re-turned to sensitize colleagues about the community policing approach.

The Maychew police have been trying to implement the initiated community policing program in crime prevention schemes in order to tackle the ever-increasing crime and disorder situations in the Town. This was done through the preparation of an implementation plan concerning the community policing program, giving workshop training for both the community policing committee members and the police, forming a neighborhood crime prevention committee and establishing the community policing structure from community household level (family police) to kebele community policing officers.

Its adoption and implementation was expected to bring a paradigm shift in preventing crime and disorder situations. Despite the expected benefits of the strategy, the numbers of crimes committed were still increasing in an alarming situation in the Town. Hence, one may ask whether initiated community policing program has been implemented to its full potential. The strategy has to be more researched and as per the researcher's observation, no research either pre or post implementation of initiated community policing program was conducted in the study area. Therefore, this problem motivated the researcher to conduct a study and to recommend possible solutions.

\subsection{Objective of the study}

The main objective of this study is to examine the implementation of community policing program in maintaining peace and security in the Case of Maychew Town, Southern Tigray, Ethiopia.

\section{Literature Review}

\subsection{Theoretical Framework}

This study was guided by two theories, namely the Social Capital Theory and the Motive-Based Trust Theory.

\subsubsection{The Motive-Based Trust Theory}

This theory postulates that poor public satisfaction with the police leads to a general public distrust to the police. This theory deals with the degree to which the police are honest and care for the members of the communities they police. Trust exists when members of the public view the police as being honest who exercise their institutional responsibilities on behalf of all citizens (Tyler, 2001).

Studies have documented that when citizens perceive an institution as trustworthy, the more likely they would comply with the institution's demands and regulations (Levi and Stoker, 2000). The more citizens perceive the police to be honest and care about their interest, the more they would comply with the police directives and decisions. This leads to citizens ${ }^{e e}$ increased trust in the police as an institution with the mandate and capability of protecting them. Motive-based trust theory supports the notion that public trust of the police can be a predictor of public satisfaction with police.

\subsubsection{Social Capital Theory}

Based on the social capital theory communities that depict greater cohesion and shared expectations also tend to have lower rates of crime and disorder. It is claimed that such strong networks of communities do have the potential for deterring crime (Field, 2003). Social capital theory has been defined as consisting features of social organization, such as networks, norms, and trust that facilitates action and cooperation for mutual benefit and results in high levels of interpersonal trust and interaction as well as high rates of civic participation (Hawdon, 2009). Thus, communities that have strong social controls are thought to have lower levels of crime and conversely, weak social capital is associated with high levels of social disorder.

\subsection{Empirical Review}

In Australia, during the 1970s a research was conducted in the areas of Community policing practices and the research identified major shortcomings such as the police could not be effective in dealing with the community problems due to the gap between the police and the community. As a result, there were lack of community active involvement, support and partnerships with the police to solve a community's crime and disorder problems (Wong, 2000).

Studies in China established that social control was decentralized and organized around communal and intimate groups, e.g., family and clan, with governmental endorsement and support (Dutton, 2012). In China, powers of control belong to the "mass". More pertinently, people are trusted to resolve their own "contradictions" (conflicts and crime). In this historical and political context, community policing in China means the people police 
themselves, i.e. personally and communally, with the police playing a subsidiary and supportive role. According to Radelet, (2009), it is the Chinese philosophy on CP which comes close to the ideal of policing articulated by the "father" of modern policing - Sir Robert Peel who observed that: "the police are the public and that the public are the police; the police are the only member of the public who are paid to give full-time attention to duties which are incumbent on every citizen in the interest of the community welfare".

\section{Methodology}

In this study, qualitative research methodology was employed to acquire knowledge from those working with community policing since that enhances the validity of their interpretations by drawing on the experiences of those most involved in the research setting itself. Qualitative research methodology according to Creswell (2009) is designed to help researchers understand peoples' attitudes, experiences and feelings about what is being studied.

This study was conducted based on an explanatory research design following more of a qualitative approach for making a detail description, diagnosis and explanation about the implementation of community policing program in maintaining peace and security in the case of Maychew Town, Southern Tigray, Ethiopia. This method was selected due to the reason that the type of data that have been collected and the nature of the research in itself was a qualitatively explanatory type.

In this study, both primary and secondary sources of data were employed in order to fill the gap that was not covered by one of them and to obtain ample information so as to realize the objectives of this study. Thus, the primary data or first-hand information was collected using semi-structured interview and focus group discussion from the study area. In addition, since relying only on primary data cannot fully capture current realities, the use of secondary sources of data was imperative. Hence, the data that was obtained from primary sources was supported by the secondary sources. To this effect, literatures and documents were used as secondary sources of data.

The target populations of this study were the community house-holds (family police) and the community policing officers who were working in the implementation of community policing program in the study area.

Purposive Sampling technique was used because according to Maina (2012), it enables the researcher to select the research participants strategically or intentionally in non-random manner based on their expertise on the phenomenon being studied since they are more familiar with the subject matter, thus they could provide the desired or accurate information that will be relevant to the researcher's focus.

In this study, semi-structured interview and focus group discussion data collection instruments were used. The semi-structured interview was applied with 4 purposively selected community policing officers from each kebeles(since there were 4 kebeles in the town) who are working in crime prevention and leading the community policing program in the town. Besides, FGDs brought together different respondents who had participated in the community policing of their kebeles. The FGDs participants were purposively selected and categorized in two 4 groups. Each group consisted of five community house-holds (family police) who have direct participation in community policing program.

Finally, following the completion of data collection, the data have been edited and structured for analysis and interpretation purposes. In the end, interpretation of data using a combination of interpretivism and constructivism to guide the qualitative method of research was conducted.

\section{Findings and Discussion}

The Ethiopian government has introduced the concept of community policing in Ethiopia in 1989, though it couldn't put in action due to different reasons until 2002, with the general objectives to reduce crime and improve police- community relations. In line with this, the police role has been decentralized up to a local administrative level that can easily be accessible to the community. The Maychew police have been trying to implement the community policing program in crime prevention schemes in order to tackle the ever-increasing crime and disorder situations in the Town. The study examined the implementation of community policing program in maintaining peace and security in the Case of Maychew Town, Southern Tigray, Ethiopia based on different perspectives as follows.

\subsection{The Community and the police knowledge regarding the theoretical concepts of CPP and its practical application}

The key informants and the focus group discussants were asked to rate their knowledge regarding the theoretical concepts of community policing program and its practical application in Maychew Town.

Accordingly, both the key informants and the focus group discussants replied that while the police had medium understanding, most of the communities have low knowledge about the theoretical concepts of community policing program and its practical application in Maychew Town. This was because of lack of willingness (due to a long-term decline in public trust in the police), and inadequate training on the detailed theory and practice of community policing. Since the training was not consistent and most of the activities were a one-off campaign, the 
community and the police did not fully understand the concept of the $\mathrm{CP} /$ community policing/ approach and its practical application. They added that without proper training, both the police and the community were less likely to understand the philosophy of CP and unable to translate the theory into effective practice.

Concomitant to this idea, Bucqueroux and Trojanowicz (2011) highlighted the fact that it is through training that the community can understand the concept of CP approach and able to translate the theoretical concepts of community policing into the practical aspects in the implementation of community policing program.

\subsection{The community policing tactics in crime prevention schemes}

According to Hughes (2008), the tactics of community policing in crime prevention are mechanisms through which crime prevention programs operate. Most of the respondents in the interview and FGDs suggested the main tactics of community policing in crime prevention activities as follows:

Community Consultation and positive interaction with the residents- according to the community policing officers, the police consult the community about options and recommendations to solve problems since problem solving should be based on a consultative approach that constantly seeks to improve responsiveness to identify and prioritize community needs. In addition, the police should take every opportunity to engage in positive interaction with all members of the community. In doing so, most community policing officers have been attending neighborhood meetings and involved in indigenous community associations like Eder and Equb in Maychew town. Moreover, the participants in the study area noted that educating the community as well as the police so as to know their responsibility in crime prevention through a community policing approach is also part of the tactics of community policing in crime prevention.

Geographic focus- the community and the police who are assigned in specific areas are responsible for small geographic areas, i.e., kebeles, so that they able to know residents, social problems and their concerns.

Involvement of Community Crime Prevention Committee- according to the key informants, people organize themselves into groups or networks to prevent local crime and other problems. For them, community crime prevention the most effective means of combating crime and improving the quality of neighborhoods life involves individual residents in proactive efforts to reduce or preclude the opportunities for crime. Moreover, the interviewees reflect that community crime prevention enables citizens involved in neighborhood watch programs taking ownership of their neighborhoods. Also, the information provided by neighborhoods watch members is used to solve and prevent crime and community crime prevention involves the participation of the community members in identifying priority issues and development of preventive approaches and engaging in efforts to reduce crime.

The use of foot patrols as well as open communications between Police and the Community-the key informants and the focus group discussants maintained that foot patrol as popular tactic of community policing, may put officers in closer contact with citizen and reduce opportunities for disorder in the town. According to the respondents, this can be done through making the policing service more accessible to the town people. Moreover, open communication between the police and members of the community is vital because $\mathrm{CP}$ sees the community as a source of information. It must be utilized because without the information from the community, the work of the police is doomed to failure.

However, some of the community respondents underlined that lack of continuous training made them not to be aware about the tactics of community policing in crime prevention schemes.

\subsection{The critical factors decreasing public trust in the police in Maychew Town}

The respondents were asked whether there are critical factors that can decrease public trust in the police in the study area or not. Accordingly, majority of the key informants and the focus group discussants identified the critical factors that can decrease public trust in the police in the study area as follows:

First, proliferation of crime- according to the respondents, fear of crime among citizens will result in a decreased public trust in the police because they view the police as not capable of ensuring their safety and security. Motive-based trust theory supports the respondentse notion by stating that the more citizens perceive the police have capability of protecting them and care about their interest, the more they would have confidence in the police and vice versa.

Second, less public satisfaction- according to the respondents, the more residents are satisfied with the police service, the greater their trust will be in the police and the less satisfied they are, the lower their level of trust. In support of this idea, the motive-based trust theory states that when citizens are satisfied with the police, they will have more trust in the police compared to citizens that are not satisfied.

Third, protection to rich people- as to the respondents, the economically powerful classes have more trust in the police since they are offered greater protection by the police as against the lower class individuals who are always under strict (control) surveillance by the police. In support of this, the conflict theory argues that persons of lower socio-economic status will tend to have little or no trust in the police due to un-fair treatment of the police against them. 
Fourth, corruption- all of the respondents indicated that police receive money from victims of crimes to initiate investigations and demand bribes from suspects to drop investigations. Corruption in the police has eroded public trust and confidence they have in the police. Moreover, Kaariainen (2007) found that the level of corruption in the system of government in general decreases public trust in the police.

Finally, trauma- according to the respondents, aged people tend to have lower levels of trust in the police than younger people. They reasoned that older people had still a legacy of terrible memories that came from past police brutal and malpractices. In support of this idea, Yeshiwas (2014), stating historically, the police in Ethiopia had lost a good relation with the community. This finding conflicts with findings of Wu and Sun (2009) which indicates that younger people have lower levels of trust in the police than older people.

\subsection{The police-community relations in maintaining peace and security}

$\mathrm{Lab}$ (2004) pointed out that the police alone do not have the necessary potential and resources to combat crime and disorder. However, majority of the respondents in the FGDs and interview noted that the police-community relations in maintaining peace and security were poor. The possible reasons they mentioned were the legacy of illegitimacy and distrust emanating from past police extra-legal, brutal and terrible memories as well as malpractices still exists between the police and the public and lack of knowledge regarding the community policing philosophy as well as due to the police departments weaknesses to include the community in policing matters.

In addition, the significant majority of key informants and the focus group discussants answered that there were some circumstances that made the community not to cooperate with the police in crime prevention such as the fear of revenge by criminals, fear of police bureaucracy and misconduct, police weakness to involve different parties in the on-going initiatives of community policing program, and corruption by which most criminals were let out from prison without proper punishment.

\subsection{Challenges affecting the implementation of community policing program in maintaining peace and security on the part of the community}

In this research, the respondents identified the major factors that affect the implementation of community policing in maintaining peace and security on the part of the community such as lack of interest, commitment and participation in community policing initiatives, poor understanding of community policing approach and its practical application, the communities mistrust /hostility/ towards the police, hiding criminals and stolen property, providing false information to the police, lack of timely feedback to police calls for consultation and community policing forums, and leaves all safety and security issues to the police in the belief that the duty of crime prevention is the sole responsibility of the police.

Concerning possible solutions for the challenges faced, the key informants and the focus group discussants suggested like increasing the community trust/confidence /in the police, educating and training the community about the community policing philosophy, and increasing the com-munity participation, commitment, willingness or interest to participate in the community policing program by giving them encouraging incentives.

\subsection{Challenges affecting the implementation of community policing Program in maintaining peace and security in the police organization}

Lack of decentralized police service; the police weakness to include the community in policing matters; lack of skills to organize the community policing forums and educating the community about the community policing initiatives; time constraint; police misconduct (treat suspects unfairly and use unnecessary force) and corruption; low accountability; low morale of the police due to poor working conditions and low pay; poor integration with stakeholders were the major hindering factors of community policing implementation efforts on the part of the police organization. Moreover, the majority of the respondents agreed that the Maychew Town police didn't provide fast, efficient, effective and less costly policing service due to the lack of commitment, lack of speedy response to emergency calls, their small number, police stations were not accessible to all residents, and police personnel were not sufficiently trained to provide an effective police service.

How could these challenges be addressed? According to the respondents of this study, the challenges that influence the implementation of community policing on the part of the police organization can be addressed through giving adequate training on the detailed theory and practical aspects of the community policing approach, allocating sufficient resources to implement community policing and ensuring decentralized police service, organizing the $\mathrm{CP}$ forum and educating the community about the $\mathrm{CP}$ program, behaving in an ethical way and fighting corruption, be accountable to the community they serve, established strong partnership with stakeholders, and develop fast and effective information exchange mechanisms.

\subsection{Factors in the government affecting the implementation of community policing program in maintaining peace and security \\ NCPI (2001) stated that the police agency should get sufficient resources to perform their policing activities. On}


the other hand, the key informants and the focus group discussants replied that the government has failed to allocate adequate budget and resources such as logistics, transport and communication facilities needed to perform CP initiatives; unable to educate and train the police force about $\mathrm{CP}$ philosophy and failed to assign sufficient and skilled manpower. They also added that the number of police officers was not proportional to the community to be served. Finally, most of the respondents indicated that there was a failure on the part of the government to formulate timely guidelines, procedures and policies required for the implementation of community policing.

\subsection{The implementation of community policing program in maintaining peace and security}

To the question: What does the overall implementation of community policing program look like in Maychew Town? Most of the respondents in the interview and FGDs responded that the implementation of CPP in Maychew Town facing a variety of challenges which made crime prevention more difficult. All in all, they said that the implementation of community policing program in maintaining peace and security was not effective in the study area.

\section{Conclusion and Recommendations \\ 5.1. Conclusion}

From the findings of this study, the following major conclusions were made in line with the objectives.

From the findings of this study, it is possible to conclude that both the police and the community did not fully understand the $\mathrm{CP}$ philosophy and unable to translate the theory into practice. In addition, the police and the community didn't work together because the police have unfriendly relationship with the communities and there is minimum public trust. Depending on the findings of this study, in a nutshell, the implementation of community policing program facing a variety of challenges on the part of the community, the police agencies and the government in the study area. Thus, the trends of crime were increasing in an alarming situation in the study area. Concomitant to this idea, the study also concludes that the implementation of community policing program in maintaining peace and security was not effective in Maychew Town.

\subsection{Recommendations}

Based on the conclusions drawn from the study, the following recommendations were given:

The study recommends that sensitization programs should be enhanced through massive awareness creation and consistent trainings in order to educate the community and the police on how community policing works and how to improve the poor police- community relationship. The study identified that there were some critical factors that can decrease community trust in the police in the study area. Therefore, the communities, the police and other concerned governmental or NGOs should coordinate to alleviate these factors by delivering effective police service to all citizens and bring the individuals committed corruption to be punished by the law.

Based on the conclusions of this study, it is recommended that workshops and seminars should be organized for the community and the police to enhance their commitment, interest and participation so as to prevent crime. The government should also allocate more funds and resources to support the operations of community policing program. The study revealed that the implementation of community policing program in maintaining peace and security was not effective in Machew Town. So that, there must be regular community policing forums to discuss how to implement the community policing program to its full potential thereby to prevent crime. By and large, the community, the police, the government and any concerned body must work cooperatively and give emphasis to support the operations of community poling program.

\section{Acknowledgment}

I am grateful to all of those with whom I have had the pleasure to work in writing this article. I thank you!!!

\section{References}

Block, R. L., Donnermeyer, J. F., \& Doeren, E. (2011). Security and Crime Prevention (2nd ed.). US: ButterworthHeinemann.

Bucqueroux, B., \& Trojanowicz, R.C. (2011). Community Policing: How to Get Started (2nd ed.). Cin cinnati, $\mathrm{OH}$ : Anderson.

Creswell, J.W. (2009). Research Design: Qualitative and Mixed methods approach (2nd ed.). London: Sage.

Dutton, M. (2012). Policing and Punishment in China. Cambridge University Press.

Field, J. (2003). Social Capital. London: Routledge.

Ford, J.K., \& Morash, M. (2002). The Move to Community Policing: Making Change Happen. California: Sage.

Frehiwot, M. (2015). Challenges and Prospects of the Implementation of Community Policing at the Uni-versity of Addis Ababa( Masters ${ }^{e}$ thesis, University of Addis Ababa, Addis Ababa, Ethiopia

Hawdon, J. (2009). Legitimacy, Trust, Social Capital, and Policing Styles: A Theoretical Statement. Police Quarterly, 11(2), 182-201. 
Hughes, G. (2008). Understanding Crime Prevention: Social Control, Risk and Late Modernity. Bucking-ham: Open University Press.

Kaariainen, J. (2007). Trust in the Police in 16 European Countries: A Multilevel Analysis. European Jour-nal of Criminology, 4 (4), 409-435.

Lab, S.P. (2004). Crime Prevention: Approaches, Practices and Evaluations (5th ed.). Upper Saddle Riv er, NJ: Prentice Hall.

Levi, M., \& Stoker, M. (2000). Political Trust and Trustworthiness: Annual Review of Political Science, 2 (3), 475-507.

Mekuriaw, D., \& Mulugeta, E. (2017). Community Policing: Practice, Roles, Challenges and Prospects in Crime Prevention in East Gojjam Administrative Zone. Social Crimonol 5: 160. Doi: 10.4172/2375-4435.1000160.

National Crime Prevention Institute. (2001). Understanding Crime Prevention. University of Louisville. Boston: Butterworth.

Palmiotto, J. (2000). Community policing: A Policing Strategy for the 21st Century. Gaithersburg, Md: Aspen.

Radelet, L.A. (2009). The Police and the Community. New York: Macmillan Publishing Company.

Tyler, R. T. (2001). Public Trust and Confidence in Legal Authorities: What Do Majority and Minority Group Members Want from the Law and Legal Institutions? Behavioral Sciences and the Law 19:215-235.

Wong, Kam C. (2000). police and Accountability. Hong Kong: Open University of Hong Kong

Wu, Y., \& Sun, I. Y. (2009). Citizen Trust in Police: The Case of China. Police Quarterly, 4 (12), 170-191.

Yeshiwas, D. (2014). Community Policing or Policing the Community? The Emerging Police Practice in Ethiopia. International Journal of Science and Research (IJSR), 3 (9), 2319-7064. Retrieved from https://www.ijsr.net/archive/v3i9/U0VQMTQ1NTE=.pdf. 